\title{
Herbicide Residues in Manure, Compost, or Hay ${ }^{1}$
}

\author{
J. A. Ferrell, P. J. Dittmar, B. A. Sellers, and P. Devkota ${ }^{2}$
}

When purchasing compost, it is important to understand that some manure-based products can contain herbicide residues that can affect the growth of sensitive plants. Manure from animals that have been fed with forage treated with aminopyralid or other closely related herbicides, such as clopyralid or picloram, can be contaminated with residue from these herbicides. These herbicide residues can severely injure legumes, solanaceous crops, and other broadleaf plants. Fortunately, a simple plant bioassay can be conducted to test for herbicide contamination. There are many options to consider if contaminated compost has been applied.

\section{Herbicide}

Aminopyralid is a highly effective herbicide that is commonly sprayed on pastures and hayfields as Milestone ${ }^{\mathrm{TM}}$, GrazonNext $\mathrm{HL}^{\mathrm{TM}}$, or Chaparral ${ }^{\mathrm{TM}}$. This herbicide is safe on grasses, but effectively manages many of our noxious and invasive broadleaf weeds, including tropical soda apple. Aminopyralid works by mimicking the natural plant growth hormone auxin. As the herbicide is absorbed into plant tissue, rapid and uncontrollable growth occurs until the plant "grows itself to death." Grasses are highly tolerant to this herbicide because they rapidly metabolize the molecule and sequester it in special parts of the cell so it is no longer available for herbicide action. Many broadleaf plants cannot accomplish the metabolism/sequestration step and succumb to herbicide effects. Fortunately, aminopyralid targets a process that is unique to plants; therefore, humans and other animals are not affected by this herbicide. Livestock can actually graze treated pastures immediately after aminopyralid application because the herbicide quickly passes through the animal with no ill effects and is excreted in manure (urine and feces).

\section{Compost}

Animal manure or compost is an ideal amendment to naturally improve soil fertility and organic matter content. However, some manure or compost may contain weed seeds, while others could potentially be contaminated with herbicide. Unfortunately, manure contamination can occur if the animal has been fed forage treated with aminopyralid or other closely related herbicides, such as clopyralid or picloram. Because aminopyralid is absorbed into plant leaves and sequestered for the leaves' lifetime, the herbicide residue will be present. This is the case even if the grass is cut, dried, and baled as hay. When this forage is fed to livestock, the leaf tissues are broken down and the herbicide

1. This document is SS-AGR-415, one of a series of the Agronomy Department, UF/IFAS Extension. Original publication date May 2017. Revised May 2020. Visit the EDIS website at https://edis.ifas.ufl.edu for the currently supported version of this publication.

2. J. A. Ferrell, professor, Agronomy Department, and director, UF/IFAS Center for Aquatic and Invasive Plants; P. J. Dittmar, associate professor, Horticultural Sciences Department; B. A. Sellers, professor, Agronomy Department, and director, UF/IFAS Range Cattle Research and Education Center; and P. Devkota, assistant professor, Agronomy Department, UF/IFAS West Florida Research and Education Center; UF/IFAS Extension, Gainesville, FL 32611. Original written by J. A. Ferrell; revised by P. Devkota.

The use of trade names in this publication is solely for the purpose of providing specific information. UF/IFAS does not guarantee or warranty the products named, and references to them in this publication do not signify our approval to the exclusion of other products of suitable composition. All chemicals should be used in accordance with directions on the manufacturer's label. Use herbicides safely. Read and follow directions on the manufacturer's label.

The Institute of Food and Agricultural Sciences (IFAS) is an Equal Opportunity Institution authorized to provide research, educational information and other services

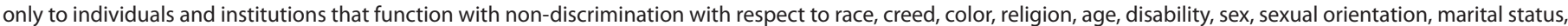

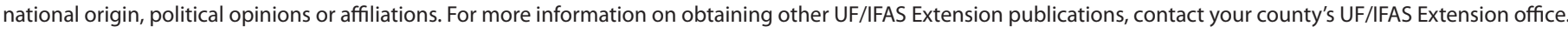
U.S. Department of Agriculture, UF/IFAS Extension Service, University of Florida, IFAS, Florida A \& M University Cooperative Extension Program, and Boards of County Commissioners Cooperating. Nick T. Place, dean for UF/IFAS Extension. 
is released within the digestive tract of the animal, then excreted in manure. For this reason, all herbicides containing aminopyralid explicitly state that manure or treated grass cannot be used as mulch or compost for sensitive broadleaf crops (Figure 1).

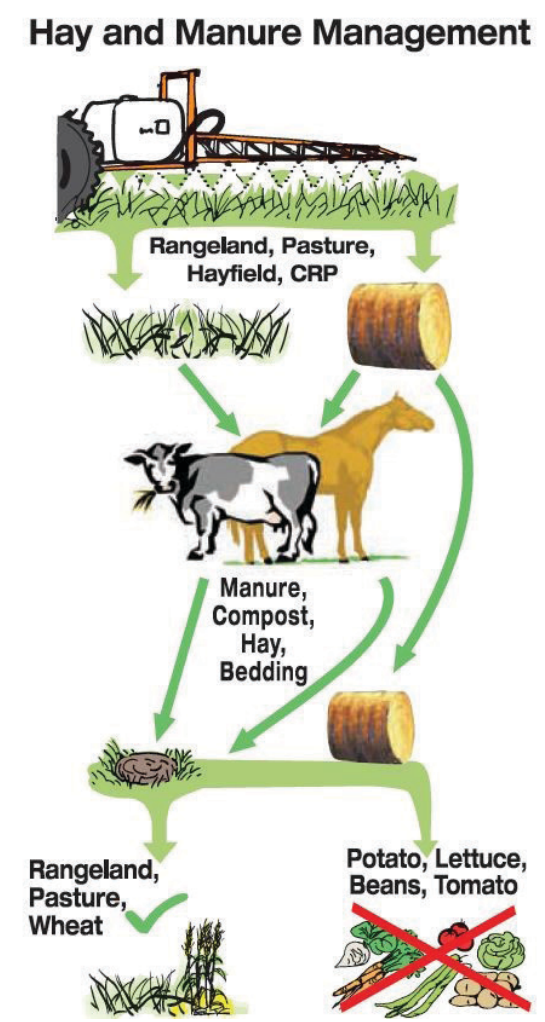

Figure 1. Illustration on the GrazonNext $\mathrm{HL}^{\mathrm{TM}}$ label describing how aminopyralid-treated forage can be handled.

Credits: Corteva Agriscience

\section{Questions to Ask When Purchasing Bulk Compost or Mulch}

When purchasing compost, specifically ask if all precautions have been taken to ensure the product is herbicidefree. If this question cannot be satisfactorily answered, or if the material will be used to produce high-value crops, it would be prudent to personally evaluate the quality of the compost by conducting a plant bioassay.

\section{Conducting a Bioassay}

A bioassay is a process where plants are used as an indicator of herbicide residues. However, not all plants are equally sensitive to aminopyralid. Grass crops, such as corn or wheat, are extremely tolerant; brassica crops (broccoli, cauliflower) are only moderately sensitive, and legume (peas and beans) and solanaceous crops (tomato, potato, pepper) are extremely sensitive. Most analytical laboratories can detect aminopyralid in soil down to concentrations of 20-50 parts per billion (ppb). Tomato plants have been shown to be profoundly affected at rates as low as $0.2 \mathrm{ppb}$. Therefore, tomato or bean plants are a far better indicator of herbicide presence.

Conduct the bioassay by taking 4-8 samples from the compost pile and filling an ordinary garden pot or plastic cup with drainage holes. Also prepare $4-8$ cups using bagged potting mix that does not contain animal manure or grass compost (a bark and sand mixture would be ideal). The bagged potting mix will serve as your control or standard for comparison. In all cups, plant 2-4 pea or tomato seeds and place in an area with adequate temperature and light to promote proper seed germination and growth. Water the cups when the soil begins to show dryness, but avoid overwatering. Monitor the plants regularly to see if herbicide symptoms develop.

If the compost has been spread onto a garden or field, the bioassay can still be conducted. A row of pea or bean seeds can be planted directly into the site and evaluated for proper growth and emergence. In a field bioassay, peas or beans are preferable to tomatoes because the larger-seeded species will often emerge faster and more evenly. If possible, also seed an area where no compost or mulch was applied to serve as your control. This process can be completed several times over weeks or months to closely monitor the herbicide concentrations that might be present.

\section{Aminopyralid Injury Symptoms}

Aminopyralid is a synthetic plant growth hormone that is highly mobile within the plant. Therefore, symptoms of aminopyralid often appear in the newest tissues and manifest as improper leaf formation and expansion (Figure 2 ). Higher concentrations will typically result in stem twisting or even root formation on the stems (Figure 3). Blooms (flowers) are quite sensitive to this herbicide and may abort even if leaf symptoms are not obvious.

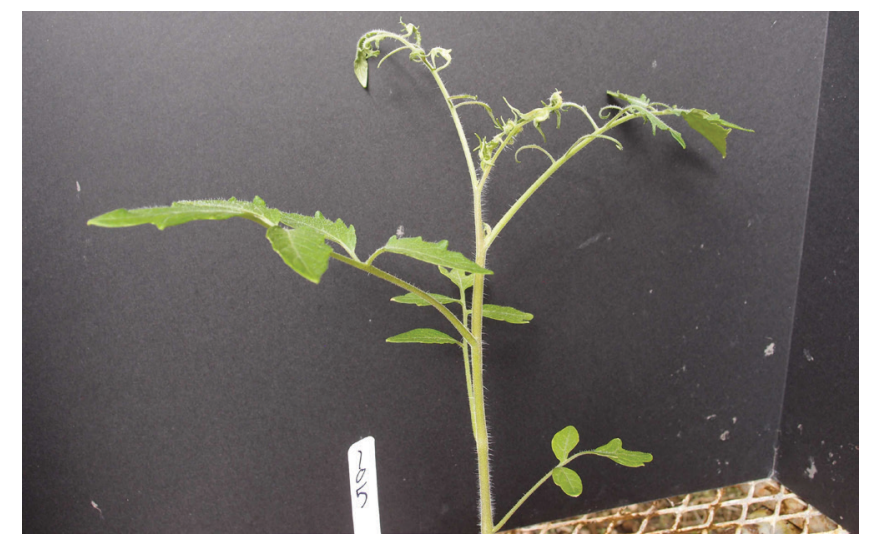

Figure 2. Low-dose aminopyralid damage on tomato. Note the damage is in the newest and most actively growing tissues. Credits: J. A. Ferrell, UF/IFAS 


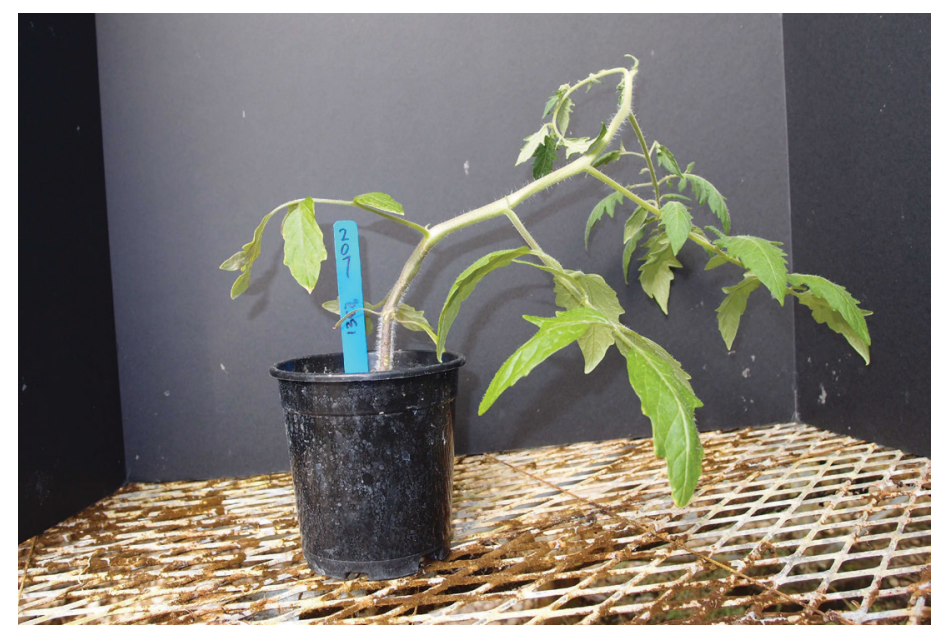

Figure 3. Higher doses of aminopyralid will result in leaf malformation and stem bending/twisting.

Credits: J. A. Ferrell, UF/IFAS

\section{Steps to Consider if Contaminated Manure or Compost Has Been Added to a Garden or Field Site}

If a bioassay confirms that your site has herbicide residues, there are many options to consider. First, the site does not have to be abandoned if a suitable crop can be chosen. If any aminopyralid is present, it will likely preclude planting carrots, any legume crop (peas and beans), or solanaceous crops (tomato, potato, pepper). Conversely, corn is highly tolerant and will grow without any adverse effects.

Remember that soil microbes are effective at converting aminopyralid into permanently inactive forms. Research has shown that the half-life (time required for half the herbicide to be broken down) of aminopyralid in soil is 34.5 days (Shaner 2014). Therefore, after some time the herbicide will be fully degraded, and the field or garden area can be returned to normal production. Keep in mind that the bioassay should always be conducted before any replanting decision is made. To hasten this process, a grass crop can be planted that will absorb herbicide from the soil. The grass can be clipped and clippings discarded onto a site labeled for aminopyralid applications (pastures, fencerows, etc.). Tilling the grass back into the soil will re-release the herbicide and start the process all over again. Additionally, breakdown of aminopyralid in plant residues or manure is more rapid under warm, moist soil conditions and may be enhanced through supplemental irrigation.

Soil removal is a laborious process, but a potentially useful one if a small area is to be reclaimed. The soil that is removed does not need to be sent to a landfill or handled as hazardous waste. Instead, the herbicide-containing soil can be applied to any site where the herbicide can legally be applied (pastures, fencerows, etc.).

\section{Conclusions}

Communication between the sellers and users of compost products is essential to ensure the products are not contaminated with herbicides. Proper stewardship of aminopyralid (see https://www.corteva.us/content/dam/dpagco/corteva/ na/us/en/products/us-pasture-management/Aminopyralid\%20Stewardship.pdf and https://www.corteva.co.uk/ manure-matters.html) will help mitigate nontarget species effects. Users of aminopyralid should read and follow all label directions. If a producer intends to sell or distribute forage products treated with aminopyralid, the recipient should be informed about the use precautions and restrictions. Proper communication can help prevent potential issues of herbicide contamination in home landscapes and gardens.

\section{Reference}

Shaner, D. L. 2014. Herbicide Handbook. $10^{\text {th }}$ ed. Lawrence, KS: Weed Science Society of America. 43-46. 